Available online at GSC Online Press Directory

GSC Biological and Pharmaceutical Sciences

e-ISSN: 2581-3250, CODEN (USA): GBPSC2

Journal homepage: https://www.gsconlinepress.com/journals/gscbps

(RESEARCH ARTICLE)

\title{
Growth and survival promotion of a probiotic bacterium Enterococcus durans enriched Artemia nauplii on the prawn Macrobrachium rosenbergii
}

Jain Indira Bhaheerathan, Bhavan Periyakali Saravana *, Dharani Chinnasamy, Manjula Thangaraj, Kalpana Ramasamy, Muralisankar Thirunavukkarasu, Karthik Madhayan and Puvitha Paramasivam

Department of Zoology, Bharathiar University, Coimbatore - 641046, Tamil Nadu, India.

Publication history: Received on 23 June 2020; revised on 06 July 2020; accepted on 08 July 2020

Article DOI: https://doi.org/10.30574/gscbps.2020.12.1.0201

\begin{abstract}
This work accentuate the growth performance of Macrobrachium rosenbergii post larvae (PL) fed with a probiotic bacterium, Enterococcus durans enriched live feed Artemia franciscana nauplii at five different serially diluted concentrations $\left(10^{-1}, 10^{-3}, 10^{-5}, 10^{-7}\right.$ and $\left.10^{-9}\right)$. After 45 days of the feeding trial, the survival rate, growth rate, activities of protease, amylase and lipase, and contents of total protein, amino acid, carbohydrate and lipid were significantly $(\mathrm{P}<0.05)$ increased, particularly at $1071 \times 10^{-7} \mathrm{CFU}$. The gut microflora of un-enriched Artemia nauplii fed prawns showed the presence of Escherichia coli, Klebsiella sp., Citrobacter sp., Acinetobacter sp., Streptococcus sp., Bacillus sp., Staphylococcus sp., and Pseduomonas sp. The optimized concentration of E. durans enriched Artemia nauplii fed prawns showed the presence of Enterococcus sp., E. coli, Bacillus sp., and Klebsiella sp. The pathogenic bacteria, Citrobacter sp., Acinetobacter sp., Streptococcus sp., Staphylococcus sp., and Pseduomonas sp., were competitively excluded in the gut of prawns due to the colony establishment of Enterococcus sp., Hence, E. durans can be used as a enrichment material of Artemia nauplii for sustainable culture of M. rosenbergii.
\end{abstract}

Keywords: Live feed; Artemia; Prawn; Probiotics; E. durans; Growth; Survival; Gut microflora; Digestive enzymes; Protein

\section{Introduction}

Aquaculture is one of the fastest growing food producing sectors in the world. It offers proteinaceous food supply to fight against malnutrition, poverty and considerably generate employment opportunity to improve rural economy. In recent years both seafood production and overall worldwide consumption has increased considerably [1]. Among crustacean, prawns provide protein, vitamins, minerals and nutritious delicacy for human consumption [2].The growth of aquaculture has resulted in environmental damages, which can be minimized through sustainable practices. The use of antibiotics and chemicals can be reduced and the outbreaks of diseases can be prevented by applications of probiotics $[3,4]$.

In aquaculture, probiotics has been extended in feed supplements, have the ability to survive and pass through the intestinal tract. They have competitively exclude pathogenic bacteria by production of inhibitory compounds in an ecofriendly manner, increase immune response, stress resistance, disease tolerance, maintain water quality, encourage reproduction and offer better growth and survival [5-20]. Probiotics increase digestibility of nutrients and feed efficiency by producing some exogenous enzymes, which increases activities of endogenous enzymes (amylase, protease and lipase) to hydrolyze nutrients, and effectively improve growth, survival and nutritional quality of the host [21-30].

\footnotetext{
${ }^{*}$ Corresponding author: Bhavan Periyakali Saravana. E-mail: bhavan@buc.edu.in
} 
The genus Enterococcus is the most controversial group of lactic acid bacteria. Enterococci are ubiquitous microorganisms, widely distributed in nature (water, plant, soil, foods, and gastrointestinal tract of humans and animals) and considered as bacteria of low pathogenicity. Enterococcus durans, Enterococcus faecium, Enterococcus faecalis and Enterococcus avium produces antimicrobial bacteriocins called enterocins, they used in food biopreservation, play an important role in the ripening of cheeses, probably through proteolysis, lipolysis, and citrate breakdown. Enterococci are nowadays have shown a very appreciable probiotic characteristics in animal nutrition and used as potential probiotic candidates in aquaculture, live cells with different beneficial characteristics such as stimulation of immunity, anti-inflammatory activity, hypocholesterolemic effect, and prevention/treatment of some diseases in hosts. At the same time, Enterococci have been associated with a number of human infections [31-35].

It has been reported that high ammonia and high dissolved oxygen in water decreased the virulence of Enterococcus in Macrobrachium rosenbergii culture medium [36, 37], and thus, Enterococcus can be used as probiotics. Enterococcus genus is isolated from the intestine of common carp and freshwater prawn M. rosenbergii [38]. Enterococcus gallinarum and Enterococcus hirae have proved with probiotic functions in M. rosenbergii $[39,40]$ when ingested in sufficient quantities. E. durans possessed quorum quenching activity (ability to grow in low $\mathrm{pH}$ ) and to produce antimicrobial agents, hence, this bacterium could be used for therapeutics [31,41]. Therefore in this study, E. durans was used as a probiotic bacterium to enrich live Artemia nauplii for feeding M. rosenbergii PL in order to assess the ability of E. durans to increase the survival and growth, activities of digestive enzymes (amylase, protease and lipase) and the contents of basic biochemical constituents (total protein, total amino acid, total carbohydrate and total lipid).

\section{Material and methods}

\subsection{Procurement of Enterococcus durans (3031) and its sub culture}

The lyophilized spores of E. durans (MTCC 3031) was purchased from Microbial Type Culture Collection (MTCC), Chandigarh, India. It was subjected to sub-culture with Nutrient broth (Hi-media, India, pH, 6.5 at Temperature, $25^{\circ} \mathrm{C}$ ), contained peptic digestion of animal tissues $\left(5 \mathrm{~g} \mathrm{~L}^{-1}\right)$, Beef extract $\left(1.5 \mathrm{~g} \mathrm{~L}^{-1}\right)$, Sodium chloride $\left(5.0 \mathrm{~g} \mathrm{~L}^{-1}\right)$, and Yeast extract $\left(1.5 \mathrm{~g} \mathrm{~L}^{-1}\right)$. The medium $(13 \mathrm{~g})$ was mixed with $1 \mathrm{~L}$ of double distilled water in a screw cap container and autoclaved at $121^{\circ} \mathrm{C}$ for 15 minutes. A loop full of E. duranswas inoculated into the broth and incubated for 24 hours at $37^{\circ} \mathrm{C}$. The appearance of turbid broth indicates the growth of $E$. durans (Figure 1). The cultured E. duranswas harvested by centrifugation at $5000 \mathrm{rpm}$ for $10 \mathrm{~min}$, washed twice with phosphate buffered saline (pH, 7.2), weighed and resuspended in the same buffer. For further usage it was stored at $4{ }^{\circ} \mathrm{C}$. The suspension $(30 \mu \mathrm{l})$ was spread over the agar plate and the appearance of white colony indicates the growth of $E$. durans (Figure 1). $20 \mu \mathrm{l}$ of serially diluted broth (up to $10^{-9}$ ) was spread on nutrient agar for enumerating the CFU in order to optimize it, and the count was 3874 at $10^{-1}$, 2671 at $10^{-3}, 1864$ at $10^{-5}, 1071$ at $10^{-7}$, and 684 at $10^{-9}$.

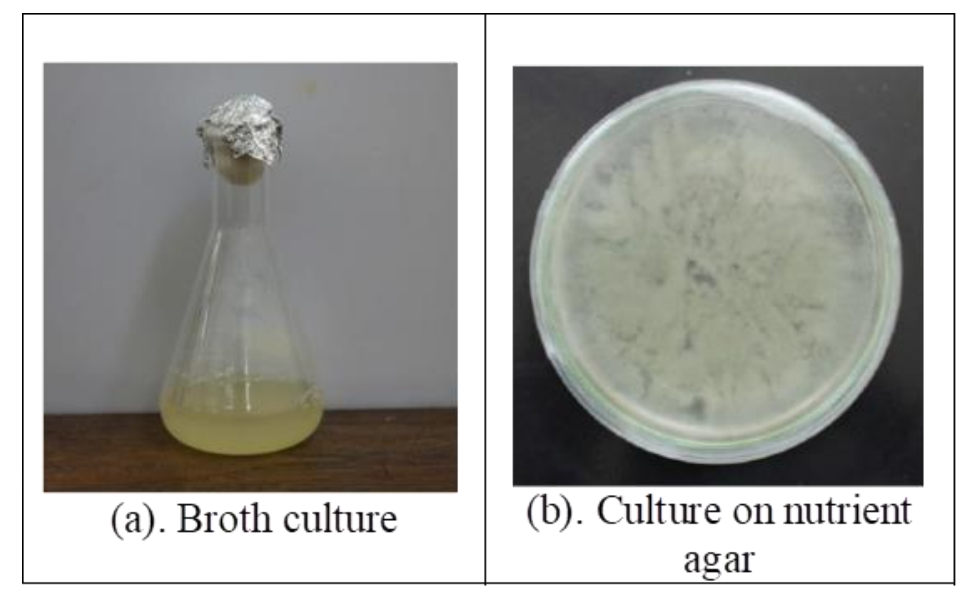

Figure 1 Culture morphology of E. durans

\subsection{Feed preparation}

All the ingredients used were micro pulverized and sieved $(0.3 \mathrm{~mm})$. For protein source, fishmeal $(25 \%)$, groundnut oil cake $(25 \%)$ and soybean meal $(25 \%)$ were used. For carbohydrate source, wheat bran $(10 \%)$ was used. Then it was steam cooked for $15 \mathrm{~min}$ at $95-100^{\circ} \mathrm{C}$ and cool at room temperature. BECOSULES CAPSULES (Pfizer Ltd., Mumbai, India) 
was used for Vitamin B complex with vitamin C (1\%). Tapioca flour (5\%) and egg albumin (7\%) were used as binding agents. Sunflower oil (2\%) was added as lipid source. The dough was prepared with adequate boiled water, pelletized in a manual pelletizer fixed with $3 \mathrm{~mm}$ diameter metal mesh, the threads were collected in aluminum trays and the semidried threads were cut into 3-5 mm pellets. The pelletized feed was dried under room temperature until the moisture content reached less than $10 \%$. The prepared feed was subjected to proximate composition analysis by adopting AOAC (1995) methodology. The feed proximate composition was as follows: Crude protein, 46.79; Total Nitrogen-free extract, 32.21; Ether extract (Crude fat), 6.19; Crude fiber, 1.33; Ash, 6.81; Moisture, 9.84; Gross energy, $4443 \mathrm{kcal} / \mathrm{kg}[39,40]$. The feed mineral content (\%) was as follows: Sand and silica (Acid insoluble ash), 0.83; Calcium, 0.80; Phosphorus, 0.90; Iron, 0.11; Copper, 0.002; Manganese, 0.008; Salt, 0.58 [39, 40].

\subsection{Enrichment of Artemia nauplii with E. durans}

The brine shrimp, Artemia franciscana cyst was purchased from Aqua world, Paris Corner, Chennai, India. The cysts (2 $\mathrm{g} / 20 \mathrm{~L}$ and $15 \mathrm{~g} \mathrm{~kg}^{-1}$ body biomass of the prawns) were taken and hydrated in $1 \mathrm{~L}^{-1}$ of purified artificial saltwater (prepared from artificial sea salt powder $35.0 \mathrm{~g} \mathrm{~L}^{-1}, \mathrm{pH}$ of 6.5) for $12-15 \mathrm{~h}$. The cysts burst and the embryo surround by the hatching membrane become visible for few hours. The brownish orange colored nauplii came out. The 48-hr old Artemia nauplii were filtered and transferred to $1 \mathrm{~L}$ capacity glass beaker. Five such groups were enriched with $3874 \times 10^{-1}, 2671 \times 10^{-3}, 1864 \times 10^{-5}, 1071 \times 10^{-7}$, and $684 \times 10^{-9}$ concentrations of E. durans for 1 hour (Figure 2). The Artemia nauplii were washed with freshwater and fed to M. rosenbergii PL.

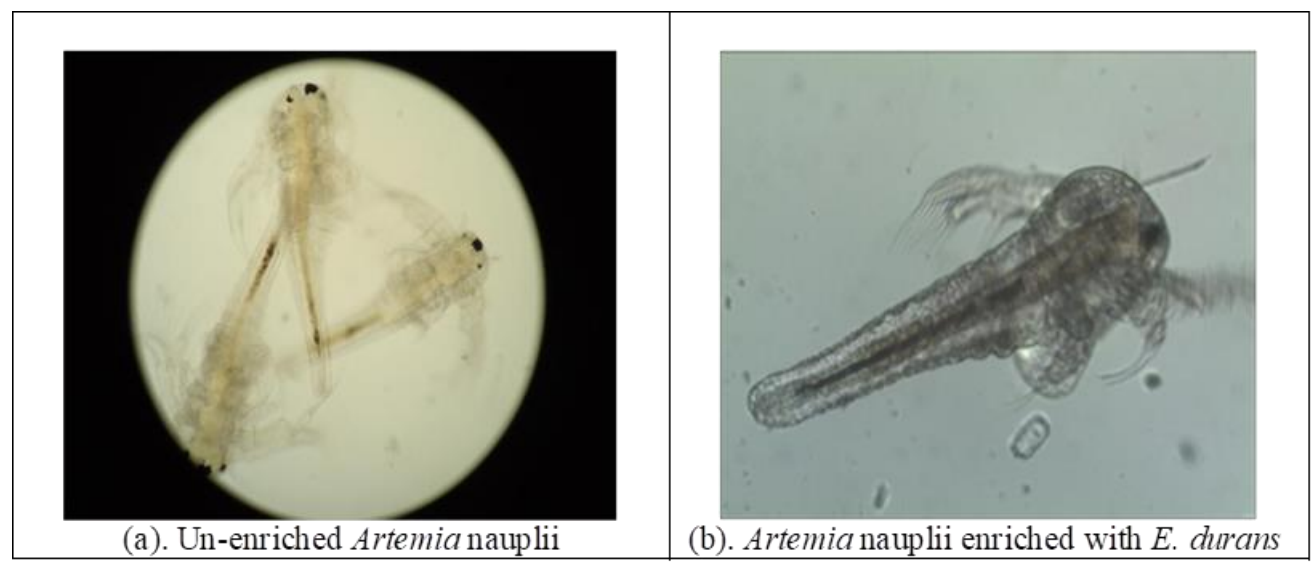

Figure 2 A. franciscana nauplii (24 hrs old)

\subsection{Procurement and acclimatization of experimental animal}

The post larvae (PL-8) of M. rosenbergii were procured from a prawn hatchery, Marakkanam, Chennai, India. They were transported to the laboratory in polythene bags filled with oxygenated water and acclimatized with ground water (Temperature, $28 \pm 2.2{ }^{\circ} \mathrm{C}$; pH, $7.4 \pm 0.10$; TDS, $0.94 \pm 0.05 \mathrm{~g} / \mathrm{L} ;$ DO $4.25 \pm 0.25 \mathrm{mg} / \mathrm{L}$; Salinity, $0.70 \pm 0.02 \mathrm{mg} / \mathrm{L} ; \mathrm{EC}$, $1.01 \pm 0.01 \mathrm{Ms} / \mathrm{cm}$; Ammonia, $0.028 \pm 0.006 \mathrm{mg} / \mathrm{L}$ ) for two weeks in cement tanks [1, 2]. During acclimatization the prawns were fed with Artemia nauplii, boiled egg albumin threads and artificially feed formulated in our laboratory. Nearly half of the tank water was renewed every day and adequately aerated in order to maintain a healthy environment. The unfed feed, faecal material, exuvia/moults, and dead prawns if any were routinely removed by siphoning without disturbing the prawns while renewing the water medium $[39,40]$.

\subsection{Feeding trial}

The feeding trials were conducted for a period of 45 days. Seven group of $M$. rosenbergii $(1.1 \pm 0.05 \mathrm{~cm}$ and $0.05 \pm 0.003 \mathrm{~g})$ were taken. The group 1 was fed with artificial feed, group 2 was fed with unenriched Artemia nauplii, and groups 3-7 were fed with E. durans $\left(3874 \times 10^{-1}, 2671 \times 10^{-3}, 1864 \times 10^{-5}, 1071 \times 10^{-7}\right.$, and $\left.684 \times 10^{-9}\right)$ enriched Artemia nauplii. Each group comprised of 30 individuals accommodated in $25 \mathrm{~L}$ of ground water. The water medium was renewed daily by siphoning and aerated. While renewing the water medium, the unfed feed, feces and moult were removed. At the end of the feeding trial the morphometric measurements were taken for calculating the nutritional indices and estimating concentrations of basic biochemical constituents, such as total protein, amino acid, carbohydrate and lipid, and activities of digestive enzymes, such as protease, amylase and lipase. 


\subsection{Calculation of nutritional indices}

The survival rate (SR), length gain (LG), weight gain (WG), and specific growth rate (SGR) were individually calculated [42].

Survival $(\%)=$ Total No. of live animals/Total No. of initial animals $\times 100$

Length gain $(\mathrm{cm})=$ Final length $(\mathrm{cm})-$ Initial length $(\mathrm{cm})$

Weight gain $(\mathrm{g})=$ Final weight $(\mathrm{g})-$ Initial weight $(\mathrm{g})$

Specific growth rate, $(\%)=\log \mathrm{W} 2-\log \mathrm{W} 1 / \mathrm{t} \times 100$

Where, W1 \& W2 = Initial and Final weight respectively $(\mathrm{g})$, and $\mathrm{t}=$ Total number of experimental days.

\subsection{Estimations of basic biochemical constituents}

The basic biochemical constituents, such as total protein, amino acid and carbohydrate were estimated in test prawns adopting standard methodologies [43-45], respectively, and the total lipid was extracted gravimetrically [46] and spectrophotometrically estimated [47]. The contents of ash and moisture were analysed [48].

\subsection{Assays of digestive enzymes activities}

Activities of digestive enzymes (protease, amylase and lipase) were assayed at $45^{\text {th }}$ day of feeding trial. The digestive tract of three prawns from each replicate were carefully dissected out and homogenized in ice-cold distilled water and centrifuged at $9000 \mathrm{~g}$ under $4{ }^{\circ} \mathrm{C}$ for $20 \mathrm{~min}$. The supernatant was used as a source of crude enzyme. Total protease activity was determined by casein-hydrolysis method of Furne et al., [49], where one unit of enzyme activity represented the amount of enzyme required to liberate $1 \mu \mathrm{g}$ of tyrosine per minute. Amylase activity was determined according to Bernfeld [50], the specific activity of amylase was calculated as milligrams of maltose liberated per gram of starch per hour (mg/g/h). Lipase activity was assayed by the method of Furne et al., [49], one unit of lipase activity was defined as the amount of free fatty acid released from triacylglycerol per unit time.

\subsection{Gut microbial colonization}

The bacterial culture was performed in the gut homogenate of experimental prawns fed with E. durans $\left(1071 \times 10^{-7}\right)$. The prawns were deactivated by kept them in freezer at $-20^{\circ} \mathrm{C}$ for 10 minutes. The surface of the prawn was sterilized with $50 \mathrm{ppm}$ formalin for 30 seconds for removing external flora. Then the digestive tract was dissected out and homogenized with phosphate buffered saline $(\mathrm{pH}, 7.2)$ under aseptic condition. The homogenate was serially diluted up to $10^{-7}$. The aliquot $(0.5 \mathrm{~mL})$ was mixed with agar nutrient broth and incubated at $35^{\circ} \mathrm{C}$ for $24 \mathrm{~h}$. The broth $(0.1 \mathrm{ml})$ was seeded on the surface of freshly prepared nutrient agar plate and incubated at $37^{\circ} \mathrm{C}$ for $24 \mathrm{~h}$. Different bacterial colonies seen were identified and confirmed through routine bacteriological tests, such as Gram's staining, motility test, Indole test, methyl red test, Voges Proskauer test, citrate utilization test, starch hydrolases, gelatin hydrolases, nitrate reduction test, oxidase test, catalase test and carbohydrate fermentation test [51]. The bacterial colony was enumerated by using the formula, Bacterial count (CFU/g) = Number of colonies $\times$ Dilution factor/Volume of sample $(\mathrm{g})$.

\subsection{Statistical analysis}

All the data were subjected to statistical analysis through one-way ANOVA and subsequent post-hoc multiple comparisons (DMRT using SPSS v20). The $P$ value less than 0.05 was considered as statistically (95\%) significant.

\section{Results and discussion}

\subsection{Survival rate and nutritional indices}

The SR, WG and SGR were found to be significantly $(P<0.05)$ higher in all concentrations of $E$. durans $\left(3874 \times 10^{-1}\right.$, $2671 \times 10^{-3}, 1864 \times 10^{-5}, 1071 \times 10^{-7}$, and $684 \times 10^{-9}$ ) enriched Artemia nauplii fed M. rosenbergii PL when compared with un-enriched Artemia nauplii and the PL fed with formulated artificial feed. Among these concentrations, $1071 \times 10^{-7}$ was produced the best growth and survival performances (Table 1; Figure 3).

Similar enhanced growth performances have been reported by following workers. Jain et al., [39, 40] in M. rosenbergii PL fed with E. gallinarum and E. hirae enriched Artemia nauplii. Seenivasan et al., [52] in M. rosenbergii fed with Lactobacillus sporogenes enriched Artemia nauplii. Ali et al., [53] in Litopenaeus vannamei PL fed with Chaetoceros gracilis and Saccharomyces cerevisiae enriched Artemia nauplii. Mahmood et al., [54] in Angelfish, Pterophyllum scalare fed with symbiotic bacterium, Pediococcus acidilactici and fructo-oligosaccharide enriched Artemia nauplii. Nadella et al., $[55,56]$ reported that Bacillus licheniformis significantly reduced the cumulative mortality rate of M. rosenbergii 
challenged with Vibrio alginolyticus, due to improved immunity. Liu et al., [18] reported a significant increase in weight gain in parrot fish, Oplegnathus fasciatus fed with the diet containing B. subtilis E20 and disease resistance against $V$. alginolyticus. Liu et al., [57] recorded that Bacillus sp., administration has increased the survival rate of kuruma shrimp, Marsupenaeus japonicas. The enhanced performance have also been reported in shrimp L. vannamei fed with microencapsulated and freeze-dried Bacillus [58], in M. rosenbergii fed with Bacillus coagulans, Binifit ${ }^{\mathrm{TM}}$, LactoBasil ${ }^{{ }_{\mathrm{p}}}{ }_{\mathrm{pus}}$ ViBact* ${ }^{*}$ B. subtilis and B. licheniformis supplemented feeds [21, 22, 26, 30, 59-61].

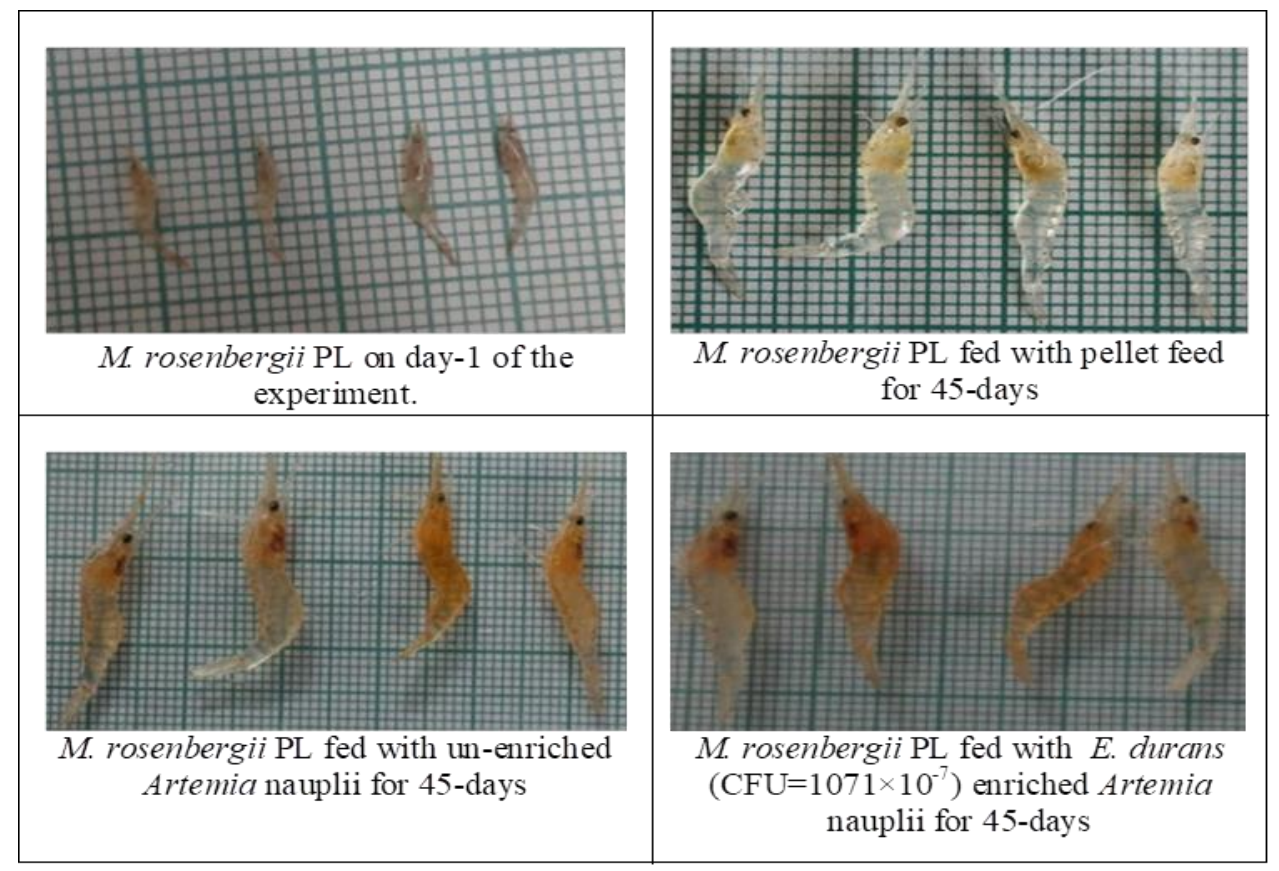

Figure 3 M. rosenbergii PL at initial and end of the experiment

\subsection{Activities of digestive enzymes}

Activities of protease, amylase and lipase were found to be significantly $(P<0.05)$ elevated in E. durans enriched Artemia nauplii fed prawns when compared with un-enriched Artemia nauplii and artificial pelletized feed. Among the different concentrations of E. durans, $1071 \times 10^{-7}$ has produced the best performance (Table 2).

Similar elevations in activities of protease, amylase and lipase have been reported by Jain et al., $[39,40]$ in $M$. rosenbergii PL fed with E. gallinarum and E. hirae enriched Artemia nauplii. Elevated activities of protease, amylase and lipase have also been recorded in M. rosenbergii PL fed with LactoBasil ${ }^{{ }_{p}}{ }_{\text {lus, }}$ ViBact*, L. sporogenes, Bacillus subtilis, S. cerevisiae, Lactobacillus brevis, Lactobacillus fermentum, B. coagulans and B. licheniformis supplemented feeds [21, 22, 24-30]. It has been reported that a significant increase in activities of digestive enzymes in Penaeus vannamei larvae when using B. coagulans and $B$. subtilis in its feeding regime [62-64]. The increases in activities of digestive enzymes have also been reported in several fish spp., when administered various probiotics: in grouper, Epinephelus coioides, Epinephelus lanceolatus and Epinephelus fuscoguttatus when supplemented with Lactococcus lactis, E. faecium, Bacillus cereus, Lactobacillus acidophilus and Clostridium butyricum [65, 66]; in the catfish, Clarias sp., against Bacillus megaterium [67]; in Tor grypus against Lactobacillus bulgaricus and Lactobacillus planturum [68]; in the common carp, Cyprinus carpio against Lactobacillus delbrueckii [69].

\subsection{Contents of basic biochemical constituents}

Concentrations of total protein, amino acids, carbohydrate, and lipids were found to be significantly $(P<0.05)$ elevated in E. durans enriched Artemia nauplii fed prawns when compared with un-enriched Artemia nauplii and artificial pelletized feed. Among the different concentrations of E. durans, $1071 \times 10^{-7}$ has produced the best performance (Table $3)$. 
Table 1 Survival and growth of M. rosenbergii PL fed with pelletized artificial feed, un-enriched Artemia nauplii and E. durans enriched Artemia nauplii for 45-days

\begin{tabular}{|c|c|c|c|c|c|c|c|c|}
\hline \multirow[b]{2}{*}{ Parameter } & \multirow[b]{2}{*}{$\begin{array}{l}\text { Pelletized } \\
\text { Artificial feed } \\
\text { fed PL. } \\
\text { Jain et al., [39, } \\
\text { 40] }\end{array}$} & \multirow{2}{*}{$\begin{array}{l}\text { Un-enriched } \\
\text { Artemianauplii } \\
\text { fed PL. } \\
\text { Jain et al., [39, } \\
40]\end{array}$} & \multicolumn{5}{|c|}{ Different concentrations of $E$. durans enriched Artemia nauplii fed PL } & \multirow[b]{2}{*}{ F-value } \\
\hline & & & $3874 \times 10^{-1}$ CFU & $2671 \times 10^{-3}$ CFU & $1864 \times 10^{-5} \mathrm{CFU}$ & $1071 \times 10^{-7} \mathrm{CFU}$ & $684 \times 10^{-9} \mathrm{CFU}$ & \\
\hline SR (\%) & $71.77 \pm 1.92^{\mathrm{f}}$ & $76.66 \pm 3.37 \mathrm{e}$ & $80.00 \pm 3.33^{\mathrm{de}}$ & $84.44 \pm 1.93^{\mathrm{cd}}$ & $90.00 \pm 3.33^{\mathrm{ab}}$ & $92.22 \pm 3.84^{\mathrm{a}}$ & $86.66 \pm 3.33^{\mathrm{ab}}$ & 17.85 \\
\hline Length $(\mathrm{cm})$ & $1.33 \pm 0.06^{\mathrm{f}}$ & $1.67 \pm 0.06^{\mathrm{e}}$ & $1.90 \pm 0.1^{\mathrm{ef}}$ & $2.11 \pm 0.12^{\mathrm{cd}}$ & $2.34 \pm 0.34 \mathrm{bc}$ & $3.08 \pm 0.11^{\mathrm{a}}$ & $2.57 \pm 0.11^{\mathrm{b}}$ & 40.98 \\
\hline Weight (g) & $0.49 \pm 0.07 \mathrm{e}$ & $0.72 \pm 0.05^{\mathrm{cd}}$ & $0.90 \pm 0.08^{\mathrm{cd}}$ & $1.17 \pm 0.28^{\mathrm{bc}}$ & $1.30 \pm 0.37^{\mathrm{abc}}$ & $1.62 \pm 0.31^{\mathrm{a}}$ & $1.36 \pm 0.12^{\mathrm{bc}}$ & 31.44 \\
\hline $\mathrm{LG}(\mathrm{cm})$ & $0.33 \pm 0.11^{\mathrm{f}}$ & $0.66 \pm 0.11^{\mathrm{e}}$ & $0.90 \pm 0.17^{\mathrm{ef}}$ & $1.11 \pm 0.10^{\mathrm{cd}}$ & $1.34 \pm 0.39 \mathrm{bc}$ & $2.08 \pm 0.05^{\mathrm{a}}$ & $1.57 \pm 0.05^{b}$ & 9.58 \\
\hline WG (g) & $0.45 \pm 0.06^{\mathrm{e}}$ & $0.67 \pm 0.05^{\mathrm{d}}$ & $0.86 \pm 0.07^{c d}$ & $1.13 \pm 0.28^{\mathrm{bc}}$ & $1.25 \pm 0.37 \mathrm{abc}$ & $1.57 \pm 0.30^{\mathrm{a}}$ & $1.31 \pm 0.11^{b c}$ & 9.85 \\
\hline SGR (\%) & $2.65 \pm 0.06^{d}$ & $2.81 \pm 0.09^{c}$ & $2.92 \pm 0.09 \mathrm{bc}$ & $3.02 \pm 0.09^{a b}$ & $3.06 \pm 0.17^{\mathrm{ab}}$ & $3.17 \pm 0.07^{a}$ & $3.09 \pm 0.10^{\mathrm{ab}}$ & 8.70 \\
\hline
\end{tabular}

nitial morphometric data: $1.1 \pm 0.05 \mathrm{~cm}$ length; $0.05 \pm 0.006 \mathrm{~g}$ weight

$\begin{aligned} & \text { Each value is mean } \pm \text { SD of three individual observations. } \\ & \text { Mean values within the same row sharing different alphabetical letter superscripts are statistically significant at } \mathrm{P}<0.05 \text { (one-way ANOVA and subsequent post-hoc multiple comparison with DMRT). }\end{aligned}$ SR, survival rate; LG, length gain; WG, weight gain, $S G R$, specific growth rate.

Table 2 Activities of digestive enzymes in M. rosenbergii PL fed with pelletized artificial feed, un-enriched Artemia nauplii and E. durans enriched Artemia nauplii for 45days

\begin{tabular}{|c|c|c|c|c|c|c|c|c|}
\hline \multirow[b]{2}{*}{$\begin{array}{l}\text { Enzyme } \\
\text { (U/mg } \\
\text { protein) }\end{array}$} & \multirow[b]{2}{*}{$\begin{array}{l}\text { Pelletized } \\
\text { Artificial feed } \\
\text { fed PL. } \\
\text { Jain et al., [39, } \\
40]\end{array}$} & \multirow{2}{*}{$\begin{array}{l}\text { Un-enriched } \\
\text { Artemia } \\
\text { nauplii fed PL. } \\
\text { Jain et al., [39, } \\
40]\end{array}$} & \multicolumn{5}{|c|}{ PL fed with different concentrations of $E$. durans enriched Artemia nauplii } & \multirow[b]{2}{*}{ F-value } \\
\hline & & & $3874 \times 10^{-1} \mathrm{CFU}$ & $2671 \times 10^{-3}$ CFU & $1864 \times 10^{-5} \mathrm{CFU}$ & $1071 \times 10^{-7} \mathrm{CFU}$ & $684 \times 10^{-9} \mathrm{CFU}$ & \\
\hline Protease & $1.44 \pm 0.04^{\mathrm{f}}$ & $1.53 \pm 0.07 \mathrm{e}$ & $1.78 \pm 0.06^{d}$ & $1.85 \pm 0.04^{\mathrm{d}}$ & $2.10 \pm 0.08^{c}$ & $2.52 \pm 0.09^{a}$ & $2.21 \pm 0.11^{b}$ & 17.85 \\
\hline Amylase & $0.62 \pm 0.08 \mathrm{e}$ & $0.74 \pm 0.05^{\mathrm{f}}$ & $0.82 \pm 0.04 \mathrm{~d}$ & $1.01 \pm 0.08^{c}$ & $1.11 \pm 0.07 \mathrm{bc}$ & $1.42 \pm 0.1^{\mathrm{a}}$ & $1.21 \pm 0.08 \mathrm{~b}$ & 40.98 \\
\hline Lipase* & $0.12 \pm 0.03^{f}$ & $0.18 \pm 0.05^{\mathrm{e}}$ & $0.20 \pm 0.07^{d}$ & $0.40 \pm 0.05^{c}$ & $0.45 \pm 0.05^{b}$ & $0.59 \pm 0.07^{a}$ & $0.49 \pm 0.09^{a b}$ & 31.44 \\
\hline
\end{tabular}


Table 3 Concentrations of basic biochemical constituents in M. rosenbergii PL fed with pelletized artificial feed, un-enriched Artemia nauplii and E. durans enriched Artemia nauplii for 45-days.

\begin{tabular}{|c|c|c|c|c|c|c|c|c|}
\hline \multirow{3}{*}{$\begin{array}{l}\text { Parameter } \\
\text { (mg/g wet wt.) }\end{array}$} & \multirow{3}{*}{$\begin{array}{l}\text { Pelletized } \\
\text { Artificial feed } \\
\text { fed PL. } \\
\text { Jain et al., [39, } \\
40]\end{array}$} & \multirow{3}{*}{$\begin{array}{l}\text { Un-enriched } \\
\text { Artemia } \\
\text { nauplii fed PL. } \\
\text { Jain et al., [39, } \\
40]\end{array}$} & \multicolumn{5}{|c|}{ PL fed with different concentrations of $E$. durans enriched Artemia nauplii } & \multirow{3}{*}{ F-value } \\
\hline & & & $3874 \times 10^{-1} \mathrm{CFU}$ & $2671 \times 10^{-3} \mathrm{CFU}$ & $1864 \times 10^{-5} \mathrm{CFU}$ & $1071 \times 10^{-7} \mathrm{CFU}$ & $684 \times 10^{-9} \mathrm{CFU}$ & \\
\hline & & & & & & & & \\
\hline Protein & $38.64 \pm 0.64 \mathrm{e}$ & $45.44 \pm 115^{\mathrm{e}}$ & $58.88 \pm 1.37^{\mathrm{d}}$ & $60.16 \pm 0.82^{\mathrm{d}}$ & $65.63 \pm 1.29 \mathrm{c}$ & $103.2 \pm 1.5^{\mathrm{a}}$ & $80.67 \pm 1.29^{b}$ & 993.93 \\
\hline Amino acid & $21.69 \pm 1.68^{\mathrm{e}}$ & $24.00 \pm 1.19^{\mathrm{d}}$ & $30.95 \pm 1.05^{\mathrm{d}}$ & $42.26 \pm 2.60^{c}$ & $49.40 \pm 0.71^{\mathrm{b}}$ & $62.63 \pm 1.21^{\mathrm{a}}$ & $51.46 \pm 1.60^{\mathrm{b}}$ & 295.42 \\
\hline Carbohydrate & $12.28 \pm 0.72^{\mathrm{d}}$ & $14.69 \pm 1.50^{\mathrm{e}}$ & $17.27 \pm 0.62^{\mathrm{d}}$ & $20.13 \pm 1.43^{c}$ & $21.60 \pm 0.66^{c}$ & $29.03 \pm 1.80^{\mathrm{a}}$ & $24.08 \pm 0.99 \mathrm{~b}$ & 69.38 \\
\hline Lipid & $5.18 \pm 0.24^{\mathrm{d}}$ & $6.92 \pm 0.36^{\mathrm{e}}$ & $8.22 \pm 0.18^{e}$ & $10.14 \pm 0.24^{\mathrm{d}}$ & $11.67 \pm 0.07^{c}$ & $15.14 \pm 0.37^{a}$ & $12.58 \pm 0.21^{b}$ & 541.21 \\
\hline
\end{tabular}


Similar increases in total protein, amino acid, carbohydrate and lipid levels have been reported by Seenivasan et al., [52] and Jain et al., [39, 40] in M. rosenbergii PL fed with L. sporogenes, E. gallinarum and E. hirae enriched Artemia nauplii. Increased contents of these basic biochemical constituents have also been recorded in $M$. rosenbergii PL fed with many probiotics supplemented diets $[21,22,25-30,59,60,70]$.

\subsection{Analysis of gut microbial consortium}

We have previously identified the presence of Escherichia coli, Klebsiella sp, citrobacter sp., Acetinobacter sp., Streptococcus sp., Bacillus sp., Staphylococcus sp., and Pseudomonas sp., in the un-enriched Artemia nauplii fed control prawn gut through colony morphology and biochemical tests $[39,40]$, when a parallel experimental set-up was maintained to study the probiotic effects of E. gallinarum, E .hirae and E. durans. In the present study, in the gut of experimental of PL fed with $1071 \times 10^{-7}$ concentration of $E$. durans enriched Artemia, the presence of Enterococcus sp., $E$. coli, Bacillus sp., and Klebsiella sp., were identified through colony morphology and biochemical tests (Tables 4 and 5; Figure 4). Therefore, the pathogenic bacteria, Citrobacter sp., Acinetobacter sp., Streptococcus sp., Staphylococcus sp., and Pseduomonas sp., were competitively excluded due to the colony establishment of Enterococcus sp.

Aquatic animals, particularly at larval stage are monogastric have difficulty in digesting complex or fibrous feedstuffs de facto, thus bacteria colonized in the gut enhanced secretion of digestive enzymes to expedite the digestion [71]. Actually, probiotics have the ability to modulated gut microbiota and subsequently improve digestive enzymes secretion which in turn improves digestion and feed utilization $[20,62,72,73]$. Probiotics are excellent source of growth promoter and provide vast nutritional benefits, among them the genera of Bacillus, could biosynthesize a wide range of extracellular enzymes, such as protease, lipase, amylase and cellulase, and other growth factors, such as biotin, vitamin $\mathrm{B}_{12}$, short-chain fatty acids, and essential amino acids $[74,75]$.

Table 4 Confirmative results of biochemical tests for micro flora present in the gut of $M$. rosenbergii PL fed with $1071 \times 10^{-7} \mathrm{CFU}$ of $E$. durans enriched Artemia nauplii

\begin{tabular}{|c|c|c|c|c|c|c|c|c|c|c|c|c|c|}
\hline \multirow[t]{2}{*}{ Test } & & \multicolumn{8}{|c|}{$\begin{array}{l}\text { Gut of PL fed with un-enriched Artemia nauplii } \\
\text { Jain et al., }[39,40]\end{array}$} & \multicolumn{4}{|c|}{$\begin{array}{l}\text { Gut of PL fed with } \\
\text { E. durans enriched } \\
\text { Artemia nauplii }\end{array}$} \\
\hline & & $E c$ & $\begin{array}{l}K \\
\text { sp., }\end{array}$ & $\begin{array}{l}C \\
\text { sp., }\end{array}$ & $\begin{array}{l}A \\
\text { sp., }\end{array}$ & $\begin{array}{l}\text { Ste } \\
\text { sp., }\end{array}$ & $\begin{array}{l}B \\
\text { sp., }\end{array}$ & $\begin{array}{l}\text { Sta } \\
\text { sp., }\end{array}$ & $\begin{array}{l}P \\
\text { sp., }\end{array}$ & $\begin{array}{l}E \\
\text { sp., }\end{array}$ & $E c$ & $\begin{array}{l}B \\
\text { sp., }\end{array}$ & $\begin{array}{l}K \\
\text { sp., }\end{array}$ \\
\hline Gram's staining & - & - & + & - & + & + & + & + & - & + & + & + & - \\
\hline Motility test & + & + & + & + & + & + & + & + & + & - & + & - & - \\
\hline Indole test & + & + & + & - & + & - & - & - & - & - & + & - & - \\
\hline Methyl red test & + & + & + & + & + & - & - & - & - & - & - & + & + \\
\hline Vp test & - & - & + & - & - & + & - & + & - & + & - & + & + \\
\hline Citrate utilization test & - & - & - & + & - & + & + & + & + & - & + & + & - \\
\hline Starch hydrolases & + & + & - & - & - & + & + & + & - & - & + & + & - \\
\hline Gelatin hydrolases & + & + & - & - & - & + & + & + & + & - & + & + & + \\
\hline Nitrate reduction test & + & + & + & + & + & + & + & + & + & + & + & - & - \\
\hline Oxidase test & + & + & - & - & - & - & - & - & + & - & - & + & + \\
\hline Catalase test & - & - & $\mathrm{A}$ & + & + & $\mathrm{A}$ & + & $\mathrm{A}$ & + & - & $\mathrm{A}$ & $\mathrm{A}$ & $\mathrm{A}$ \\
\hline Glucose test & $\mathrm{A}$ & A & $\mathrm{A}$ & + & + & $\mathrm{A}$ & $\mathrm{A}$ & $\mathrm{A}$ & $\mathrm{A}$ & $\mathrm{A}$ & $\mathrm{A}$ & NA & $\mathrm{A}$ \\
\hline Lactose test & $\mathrm{A}$ & $\mathrm{A}$ & $\mathrm{A}$ & + & + & $\mathrm{A}$ & $\mathrm{A}$ & $\mathrm{A}$ & NA & $\mathrm{A}$ & $\mathrm{A}$ & $\mathrm{A}$ & $\mathrm{A}$ \\
\hline Sucrose test & $\mathrm{A}$ & $\mathrm{A}$ & $\mathrm{A}$ & + & - & $\mathrm{A}$ & $\mathrm{A}$ & $\mathrm{A}$ & A & $\mathrm{A}$ & $\mathrm{A}$ & A & A \\
\hline Manitol test & A & A & A & + & - & $\mathrm{A}$ & A & A & A & NA & NA & A & $\mathrm{A}$ \\
\hline Maltose test & NA & NA & $\mathrm{A}$ & + & - & NA & $\mathrm{A}$ & NA & $\mathrm{A}$ & $\mathrm{A}$ & - & + & - \\
\hline
\end{tabular}

+, Positive; -, Negative; A, Acid production; NA, No acid production. Ec, Escherichia coli; K sp., Klebsiella sp.,; C sp., Citrobacter sp.; A sp., Acetinobacter sp.,; Ste sp., Streptococcus sp.,; B sp., Bacillus sp.,; Sta sp., Staphylococcus sp.,; P sp., Pseudomonas sp.,; E sp., Enterococcus sp., 
Table 5 Bacterial consortium in the gut of M. rosenbergii PL fed with un-enriched and $1071 \times 10^{-7} \mathrm{CFU}$ E. durans enriched Artemia nauplii

\begin{tabular}{lll}
\hline Samples & Identified species & Composition (\%) \\
\hline & E. coli & 10 \\
& Klebsiella sp., & 8 \\
& Citrobacter sp., & 15 \\
Gut of PL fed with & Acinetobacter sp., & 12 \\
un-enriched Artemia & Streptococcus sp., & 11 \\
nauplii. & Bacillus sp., & 18 \\
Jain et al., [1, 2] & Staphylococcus sp., & 10 \\
& Pseduomonas sp., & 11 \\
& Total & 93 \\
Gut of PL fed with E. & E. coli & 32 \\
durans enriched & Bacillus sp., & 23 \\
Artemia nauplii & Klebsiella sp., & 9 \\
& Total & 87 \\
\hline
\end{tabular}

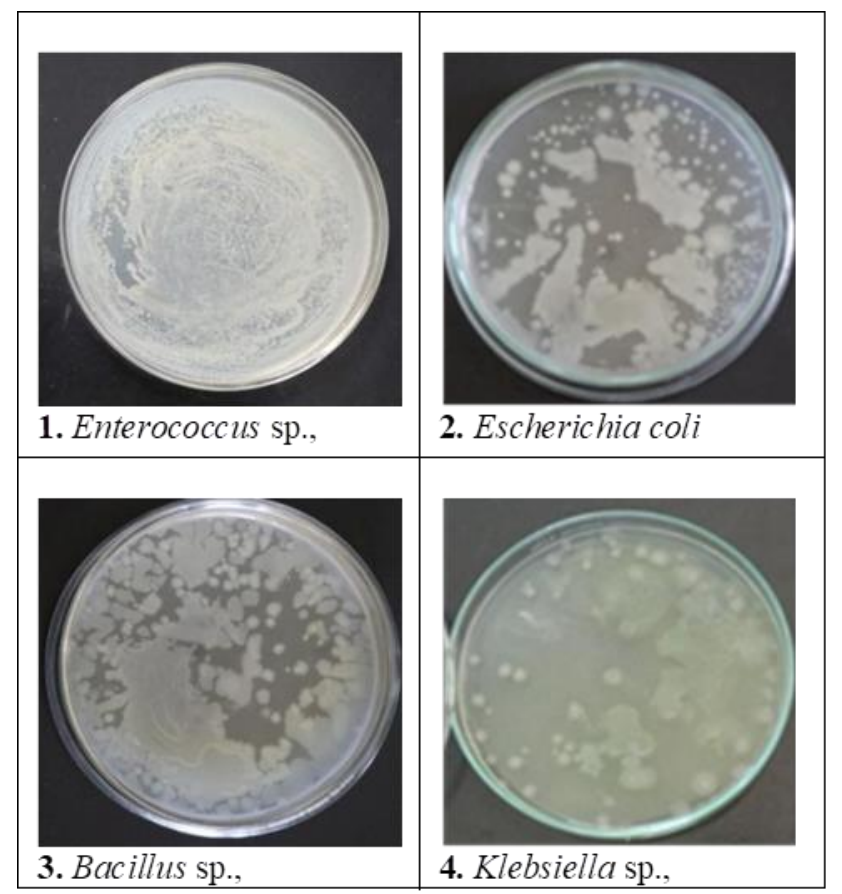

Figure 4 Agar plate morphology of different bacteria cultured from the gut of M. rosenbergii PL fed with E. durans (CFU $1071 \times 10^{-7}$ ) enriched Artemia nauplii

It is well known that the microbiota in the gut of aquatic animals can be modified by ingestion of other microorganisms, and therefore, microbial manipulation constitutes a viable tool to eliminate the incidence of opportunist pathogens by maintaining bacterial antagonism (Balcazar, 2002). Competitive exclusion of potential pathogenic bacteria effectively reduces or eliminates the need for antibiotic prophylaxis. For example, Vibrio alginolyticus has been used to increase survival and growth of L. vannamei PL [76]. Bacillus sp., and E. faecalis improved growth performance in L. vannamei [77]. The lactic acid bacteria enhance the crude protein and ash content in juveniles of $P$. indicus [78]. 
Enterococcus lactis isolated from shrimp samples of $P$. vannamei possesses antagonistic activity against pathogenic bacteria such as Listeria monocytogenes, Pseudomonas aeruginosa, Lactococcus garvieae and against fungi (Aspergillus niger and Fusarium equiseti). The bacteriocin produced by E. lactis was thermostable, active in the $\mathrm{pH}$ range from 4.0 to 9.0 , has a bactericidal mode of action, showed lack of significant antibiotic resistance genes, virulence determinants and absence of haemolytic activity, and thus recommended to be used as a natural additive or adjunct protective culture in food biopreservation and/or probiotic [79]. It has been reported that E. durans and L. lactis have in vitro suppression of growth of Escherichia coli, Staphylococcus aureus and Shigella flexneri and therefore, they emerged as new probiotics [80].

\section{Conclusion}

The present study concluded that the probiotic bacterium, E. durans has got colonized in the gut of M. rosenbergii, eliminated some pathogenic bacteria Citrobacter sp., Acinetobacter sp., Streptococcus sp., Staphylococcus sp., and Pseduomonas sp., and also enhanced the survival and growth. Furthermore, E. durans increased activities of digestive enzymes which in turn improve digestibility and absorption of nutrients in M. rosenbergii, which ultimately improved the contents of basic biochemical constituents. Therefore, it can be taken as a probiotics to maintain sustainability in prawn culture.

\section{Compliance with ethical standards}

\section{Acknowledgments}

The first author is gratefully acknowledging Bharathiar University, Coimbatore, India for providing research facility.

\section{Disclosure of conflict of interest}

There is no conflict of interest.

\section{References}

[1] FAO. (2016). The state of world fisheries and aquaculture (SOFIA): Contributing to food security and nutrition for all. Food and Agriculture Organization, Rome, 200.

[2] Bhavan PS, Radhakishnan S, Seenivasan C, Shanti R, Poongodi R and Kannan S. (2010). Proximate composition and profile of amino acids and fatty acids in the muscle of adult males and females of commercially viable prawn species in Macrobrachium rosenbergii collected from natural culture environment. International Journal of Biology, 2(2), 107-119.

[3] Jiravanichpaisal P, Chuaychuwong P and Menasveta P. (1997). The use of Lactobacillus sp., as the probiotic bacteria in the giant tiger shrimp (Penaeus monodon Fabricius), Poster session of the $2^{\text {nd }}$ Asia-Pacific marine biotechnology conference and $3^{\text {rd }}$ Asia-pacific conference on algal biotechnology, Phuket, Thailand, 16.

[4] Verschuere L, Heang H, Criel G, Dafnis S, Sorgeloos P and Verstraete W. (2000). Selected bacterial strains protect Artemia sp., from the pathogenic effects of Vibrio proteolyticus CW8T2. Applied and Environmental Microbiology, 66, 1139-1146.

[5] Rengpipat S, Phianphak W, Piyatiratitivorakul S and Menasaveta P. (1998). Effects of a probiotic bacterium in black tiger shrimp Penaeus monodon survival and growth. Aquaculture, 167, 301-313.

[6] Holmstrom C and Kjelleberg S. (1999). Marine Pseudoalteromonas species are associated with higher organisms and produce biologically active extracellular agents. FEMS Microbiology Ecology, 30, 285-293.

[7] Mariel G, Fabiano T and Jenny R. (2004). Selection of probiotic bacteria and study of their immunostimulatory effect in Penaeus vannamei. Aquaculture, 233, 1-14.

[8] Al-Dohail MA, Hashim R and Aliyu-Paiko M. (2009). Effects of the probiotic, Lactobacillus acidophilus on the growth performance, haematology parameters and immunoglobulin concentration in African catfish (Clarias gariepinus, Burchell 1822) fingerling. Aquaculture Research, 40, 1642-1652.

[9] Merrifiled DL, Dimitroglou A, Foey A, Davies SJ, Baker RTM, Bogwald J, Castex M and Ringgo E. (2010). The current status and future focus of probiotic and prebiotic applications for salmonids. Aquaculture, 302, 1-18. 
[10] Cruz PM, Ibanez AL, Hermosillo OAM and Saad HCR. (2012). Use of Probiotics in Aquaculture. ISRN Microbiology, Article ID 916845, 13.

[11] Mohapatra S, Chakraborty T, Prusty AK, Das P, Paniprasad K and Mohanta KN. (2012). Use different microbial probiotic in the diet of rohu Labeo rohita fingerlings: effect on growth, nutrient digestibility and retention, digestive enzyme activities and intestinal microflora. Aquaculture Nutrition, 18, 1-11.

[12] Perez-Sanchez T, Ruiz-Zarzuela I, Blas ID and Balcazar JL. (2013). Probiotics in aquaculture: a current assessment. Reviews in Aquaculture, 5, 1-14.

[13] Newaj-Fyzul A, Al-harbi AH and Austin B. (2014). Review: Developments in the use of probiotics for disease control in aquaculture. Aquaculture, 431, 1-11.

[14] Dawood MAO, Koshio S, Ishikawa M and Yokoyama S. (2015). Effects of heat-killed Lactobacillus plantarum (LP20) supplemental diets on growth performance, stress resistance and immune response of red sea bream Pagrus major. Aquaculture, 442, 29-36.

[15] Kumar V, Roy S, Meena DK and Sarkar UK. (2016). Application of probiotics in shrimp aquaculture: Importance, mechanisms of action, and methods of administration. Reviews in Fisheries Science and Aquaculture, 24, 342368.

[16] Zheng CN and Wang W. (2016). Effects of Lactobacillus pentosuson the growth performance, digestive enzyme and disease resistance of white shrimp Litopenaeus vannamei (Boone, 1931). Aquaculture Research, 48(6), 1-11.

[17] Chumpol S, KantachoteNitoda T and Kanzaki H. (2017). The roles of probiotic purple nonsulfur bacteria to control water quality and prevent acute hepatopancreatic necrosis disease (AHPND) for enhancement growth with higher survival in white shrimp (Litopenaeus vannamei) during cultivation. Aquaculture, 473, 327-336.

[18] Liu CH, Wu K, Chu TW and Wu TM. (2018). Dietary supplementation of probiotic, Bacillus subtilis E20, enhances the growth performance and disease resistance against Vibrio alginolyticus in parrot fish (Oplegnathus fasciatus). Aquaculture International, 26(1), 63-74.

[19] Madani NSH, Adorian TJ, Farsani HG and Hoseinifar SH. (2018). The effects of dietary probiotic Bacilli (Bacillus subtilis and Bacillus licheniformis) on growth performance, feed efficiency, body composition and immune parameters of whiteleg shrimp (Litopenaeus vannamei) postlarvae. Aquaculture Research, 49(5), 1926-1933.

[20] Tsai CY, Chi CC and Liu CH (2019). The growth and apparent digestibility of white shrimp, Litopenaeus vannamei are increased with the probiotic, Bacillus subtilis. Aquaculture Research, 50(5), 1475-1481.

[21] Jayanthi L, Bhavan PS, Srinivasan V, Muralisankar T and Manickam N. (2015a). Probiotics product

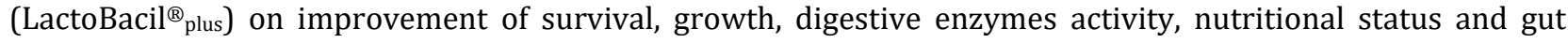
microflora of the prawn Macrobrachium rosenbergii. International Journal of Current Research, 7, 11440-11453.

[22] Jayanthi L, Bhavan PS, Srinivasan V, Muralisankar T and Manickam N. (2015b). Dietary supplementation of probiotics product (ViBact*) on the survival, growth, biochemical constituents and gut microflora of the giant freshwater prawn Macrobrachiumrosenbergii post-larvae. Asian Journal of Biochemical and Pharmaceutical Research, 2, 67-88.

[23] Adeoye AA, Yomla R, Torren AJ, Rodiles A, Merrifield DL and Davies SJ. (2016). Combined effects of exogenous enzymes and probiotic on nile tilapia (Oreochromis niloticus) growth, intestinal morphology and microbiome. Aquaculture, 463, 61-70.

[24] Seenivasan C, Radhakrishnan S, Muralisankar T and Saravana Bhavan P. (2016). Effects of probiotics on survival, growth and digestive enzymes activities in freshwater prawn (Macrobrachium rosenbergii De Man 1879). Proceedings of the Zoological Society of London, 69(1), 52-60.

[25] Narmatha V, Bhavan PS, Karthik M, Srinivasan V, Mahendran R and Satgurunathan, T. (2017). Lactobacillus fermentum on ammonia reduction and growth promotion of Macrobrachium rosenbergii post larvae, and in vitro competitive exclusions of pathogenic bacteria. International Journal of Fisheries and Aquatic Studies, 5(1), 506514.

[26] Karthik M and Bhavan PS. (2018). Supplementation of Lactobacillus brevis for Growth Promotion of the Freshwater Prawn Macrobrachium rosenbergii Post Larvae and identification of Gut Microflora through 16s rDNA. Research Journal of Biotechnology, 13(1), 34-50. 
[27] Karthik M, Bhavan PS and Manjula T. (2018a). Growth Promoting Potential and Colonization Ability of Probiotics (Bacillus coagulans and Bacillus subtilis) on the Freshwater Prawn Macrobrachium rosenbergii Post-Larvae. Insights in Biology and Medicine, 2, 007-018.

[28] Karthik M, Bhavan PS, Seenivasan V, Asaikkutti A, Muralisankar T and Mahendran R. (2018b). Dietary Supplementation of Lactobacillus fermentum for Improving the Survival, Growth and Nutritional Profiles of the Prawn Macrobrachium rosenbergii, and 16S rDNA based Identification of its Establishment. Scholar Reports, 3(1), 06, 38-62.

[29] Manjula S, Bhavan PS, Karthik M, Anitha D, Kalpana R and Manjula T. (2018). Survival, Growth, Activities of Digestive Enzymes, Concentrations of Basic Biochemical Constituents and Competitive Exclusion of Pathogenic Bacteria in Bacillus coagulans Supplemented Diet Fed Macrobrachium rosenbergii Post-Larvae. International Journal of Research Studies in Science, Engineering and Technology, 5(12), 9-22.

[30] Sudha A, Bhavan PS, Manjula T, Kalpana R and Karthik M. (2019). Bacillus licheniformis as a probiotic bacterium for culture of the prawn Macrobrachium rosenbergii. Research Journal of Life Sciences, Bioinformatics, Pharmaceutical and Chemical Sciences, 5(4), 44-61.

[31] Moreno MRF, Sarantinopoulos P, Tsakalidou E and De-Vuyst. (2006). The role and application of enterococci in food and health. International Journal of Food Microbiology, 106, 1-24.

[32] Hanchi H, Mottawea W, Sebei K and Hammami R. (2018). The Genus Enterococcus: Between Probiotic Potential and Safety Concerns - An Update. Frontiers in Microbiology, 9, 1791.

[33] Igbinos EO and Beshiru A. (2019). Antimicrobial Resistance, Virulence Determinants, and Biofilm Formation of Enterococcus Species from Ready-to-Eat Seafood. Frontiers in Microbiology, 10, 728.

[34] Braiek OB and Smaoui S. (2019). Enterococci: Between Emerging Pathogens and Potential Probiotics. BioMed Research International, Article ID 5938210, 13.

[35] Nami Y, Bakhshayesh RV, Jalaly HM, Lotfi H, Eslami S and Hejazi MA. (2019). Probiotic Properties of Enterococcus Isolated From Artisanal Dairy Products. Frontiers in Microbiology, 10, 300.

[36] Cheng W and Chen JC. (2002). The virulence of Enterococcus to freshwater prawn Macrobrachium rosenbergii and its immune resistance under ammonia stress. Fish \& Shellfish Immunology, 12, 97-109.

[37] Cheng W, Liu CH, Hsu JP and Chen JC. (2002). Effect of hypoxia on the immune response of giant freshwater prawn Macrobrachium rosenbergii and its susceptibility to pathogen Enterococcus. Fish \& Shellfish Immunology, 13, 351-365.

[38] Cai YM, Suyanandana P, Saman P and Benno Y. (1999). Classification and characterization of lactic acid bacteria isolated from the intestine of common carp and freshwater prawns. Journal of General and Applied Microbiology, $45,177-184$.

[39] Jain IB, Bhavan PS,Kalpana R, Manjula T, Dharani C, Muralisankar T, Veerapandi A and Karthik M. (2020a). Performance of probiotic bacterium, Enterococcus gallinarum enriched Artemia franciscana nauplii on survival, growth and basic biochemical constituents of the prawn Macrobrachium rosenbergii post larvae. Scholars Academic Journal of Biosciences, 8(2), 13-22.

[40] Jain IB, Bhavan PS,Manjula T, Dharani C, Kalpana R, Muralisankar T, Aiswaryalakshmi S and Karthik M. (2020b). Growth Performance of the Prawn Macrobrachium rosenbergii Post Larvae Fed with Probiotic Bacterium, Enterococcus hirae Enriched Artemia franciscana Nauplii. International Journal of Zoological Investigations, 6(1), 107-121.

[41] Boopathi S, Selvakumar G and Sivakumar N. (2017). Quorum quenching potentials of probiotic Enterococcus durans LAB38 against methicillin resistant Staphylococcus aureus. Asian Journal of Pharmaceutical and Clinical Research,10(4), 445-450.

[42] Tekinay AA and Davies SJ. (2001). Dietary carbohydrate level influencing feed intake, nutrient utilisation and plasma glucose concentration in the rainbow trout (Oncorhynchus mykiss). Turkish Journal of Veterinary and Animal Sciences, 25, 657-666.

[43] Lowry OH, Rosebrough WJ, Fair AL and Randall RJ. (1951). Protein measurement with the folin phenol reagent. Journal of Biological Chemistry, 193, 265-275.

[44] Moore S and Stein WH. (1948). Methods in Enzymology (Eds: Olowick, Spand Kalpan, ND), Academic Press, New York, 468. 
[45] Roe JH. (1995). The determination of sugar and blood and spinal fluid with anthrone reagent. Journal of Biological Chemistry, 212, 335-343.

[46] Folch J, Lees M and Bloane-Stanely GH. (1957). A simple method for the isolation and purification of total lipids from animal tissues. Journal of Biological Chemistry, 266, 497-509.

[47] Barnes H and Blackstock J. (1973). Estimation of lipids in marine animals and tissues. Detail investigation of the sulphophosphovanillin method for total lipids. Journal of Experimental Marine Biology and Ecology, 12, 103-118.

[48] AOAC. (1995). Official methods of analysis of association of analytical communities international. 2 vol. $16^{\text {th }}$ ed. Arlington, VA, USA.

[49] Furne M, Hidalgo MC, Lopez A, Garcia Gallego M, Morales AE and Domezain A. (2005). Digestive enzyme activities in adriatic sturgeon (Acipenser naccarii) and rainbow trout (Oncorhynchus mykiss), A comparative study. Aquaculture, 250, 391-398.

[50] Bernfeld P. (1955). Amylases, in: Colowick S.P., Kaplan N.O., ed., Methods in Enzymology. Academic Press, New York, 149-158.

[51] Holt JG, Krie NR, Sneath PHA, Stately JT and Williams ST. (1996). Bergey's Manual of Determinative Bacteriology, $9^{\text {th }}$ ed. Baltimore, Williams and Wilkins, 787.

[52] Seenivasan C, Radhakrishnan S, Muralisankar T and Saravana Bhavan P. (2012). Bacillus subtilis on survival, growth, biochemical constituents and energy utilization of the freshwater prawn Macrobrachium rosenbergii post larvae. Egyptian Journal of Aquatic Research, 38, 195-203.

[53] Ali A, Mansour TM, Naser A andMahmoud NB. (2017). Effects of enriched Artemia with Saccharomyces cerevisiae and Chaetoceros gracilis on growth performance, stress resistance and fatty acid profile of Litopenaeus vannamei post larvae. International Journal of Fisheries and Aquatic Studies, 5(2), 669-673.

[54] Mahmood A, Saeed M, Nasrollah A and Seyed HH. (2016). The effects of feeding with synbiotic (Pediococcus acidilactici and fructooligosaccharide) enriched adult Artemia on skin mucus immune responses, stress resistance, intestinal microbiota and performance of angelfish (Pterophyllum scalare). Fish and Shellfish Immunology, 54, 516-522.

[55] Nadella RK, Prakash RR, Jadhao SB, Brahmchari RK, Kumar K and Dash G. (2013). Effect of dietary supplementation of Bacillus licheniformis on gut microbiota, growth and immune response in giant freshwater prawn Macrobrachium rosenbergii (de Man, 1879). Aquaculture International, 21, 387-403.

[56] Nadella RK, Prakash RR, Dash G, Ramanathan, SK, Kuttanappilly LV and Mothadaka MP. (2017). Histopathological changes in giant freshwater prawn Macrobrachium rosenbergii (de Man 1879) fed with probiotic Bacillus licheniformis upon challenge with Vibrio alginolyticus. Aquaculture Research, 1-12.

[57] Liu H, Liu M, Wang B, Jiang K, Jiang S, Sun S and Wang L. (2010). PCR-DGGE analysis of intestinal bacteria and effect of Bacillus sp. On intestinal microbial diversity in kuruma shrimp (Marsupenaeus japonicus). Chinese Journal of Oceanology and Limnology, 28, 808-814.

[58] Nimrat S, Suksawat S, BoonthaiT and Vuthiphandchai V. (2012). Potential Bacillus probiotics enhance bacterial numbers, water quality and growth during early development of white shrimp (Litopenaeus vannamei). Veterinary Microbiology, 159, 443-450.

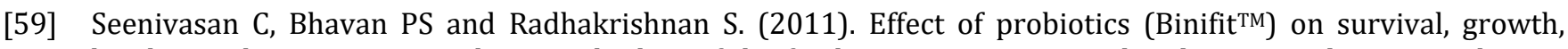
biochemical constituents and energy budget of the freshwater prawn Macrobrachium rosenbergii post larvae. Elixir Aquaculture, 41, 5919-5927.

[60] Seenivasan C, Radhakrishnan S, Shanthi R, Muralisankar T and Saravana Bhavan P. (2014). Effect of Lactobacillus sporogeneson survival, growth, biochemical constituents and energy utilization of freshwater prawn Macrobrachium rosenbergii post larvae. Journal of Basic and Applied Zoology, 67, 19-24.

[61] Gupta A, Verma G and Gupta P. (2016). Growth performance, feed utilization, digestive enzyme activity, innate immunity and protection against Vibrio harveyi of freshwater prawn Macrobrachium rosenbergii fed diets supplemented with Bacillus coagulans. Aquaculture International, 24,1379-1392.

[62] Zhou XX, Wang YB and Li WF. (2009). Effect of probiotic on larvae shrimp (Penaeus vannamei) based on water quality, survival rate and digestive enzyme activities. Aquaculture, 287, 349-353. 
[63] Liu CH, Chiu CS, Ho PL and Wang SW. (2009). Improvement in the growth performance of white shrimp (Litopenaeus vannamei), by a protease-producing probiotic Bacillus subtilis E20, from natto. Journal of Applied Microbiology, 107(3), 1031-1041.

[64] Nasim SHM, Taida JA, Hamed GF and Seyed HH. (2018). The effects of dietary probiotic Bacilli (Bacillus subtilis and Bacillus licheniformis) on growth performance, feed efficiency, body composition and immune parameters of whiteleg shrimp (Litopenaeus vannamei) post larvae. Aquaculture Research, 49, 1926-1933.

[65] Sun Y-Z, Yang H-L, Ma R-L, Song K and Li J-S. (2012). Effect of Lactococcus lactis and Enterococcus faecium on growth performance, digestive enzymes and immune response of grouper (Epinephelus coioides). Aquaculture Nutrition, 18 (3), 281-289.

[66] Rui-Peng H, Jie F, Xiang-Li T, Shuang-Lin D and Bin W. (2017). Effects of dietary supplementation of probiotics on the growth, activities of digestive and non-specific immune enzymes in hybrid grouper (Epinephelus

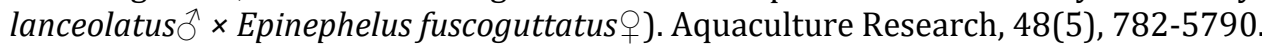

[67] Afrilasari W, Widanarni W and Meryandini A. (2016). Effect of probiotic Bacillus megaterium PTB 1.4 on the population of intestinal microflora, digestive enzyme activity and the growth of catfish (Clarias sp.). Hayati Journal of Biosciences, 23, 168-172.

[68] Mohammadian T, Alishahi M, Tabandeh MR, Ghorbanpoor M and Gharibi D. (2017). Effect of Lactobacillus plantarumand Lactobacillus delbrueckii subsp. bulgaricus on growth performance, gut microbial flora and digestive enzymes activities in (Tor grypus Karaman, 1971). Iranian Journal of Fisheries Sciences, 16(1), 296317.

[69] Zhang C, Zhang J, Fan W, Huang M and Liu M. (2018). Effects of dietary Lactobacillus delbrueckii on growth performance, body composition, digestive and absorptive capacity, and gene expression of common carp (Cyprinus carpio, Huanghevar). Aquaculture Nutrition, 25 (1), 166-175.

[70] Seenivasan C, Bhavan PS, Radhakrishnan S, Muralisankar T, Immanuel G, Srinivasan V and Manickam N. (2013). Effect of Saccharomyces cerevisiae on survival, growth, biochemical constituents and energy utilization in the prawn Macrobrachium rosenbergii. International Journal of Applied Biology and Pharmaceutical Technology, 4, 39-47.

[71] Dawood MAO and Koshio S. (2016). Recent advances in the role of probiotics and prebiotics in carp aquaculture: a review. Aquaculture, 454, 243-251.

[72] Ziaei-Nejad S, Rezaei MH, TakamiGA, Lovett DL, Mirvaghefi AR and Shakouri M. (2006). The effect of Bacillus sp. bacteria used as probiotics on digestive enzyme activity, survival and growth in the Indian white shrimp (Fenneropenaeus indicus). Aquaculture, 252, 516-524.

[73] Wang YB, Fu LL and Lin J. (2012). Probiotic (Bacillus coagulans) cells in the diet benefit the white shrimp (Litopenaeus vannamei). Journal of Shellfish Research, 31(3), 855-860.

[74] De D, Raja RA, Ghoshal TK, Mukherjee S and Vijayan KK. (2018). Evaluation of growth, feed utilization efficiency and immune parameters in tiger shrimp (Penaeus monodon) fed diets supplemented with or diet fermented with gut bacterium Bacillus sp. DDKRC1. Isolated from gut of Asian seabass (Lates calcarifer). Aquaculture Research, 49, 2147-55.

[75] Nimrat S, Khaopong W, Sangsong J, Boonthai T and Vuthiphandchai V. (2019). Dietary administration of Bacillus and yeast probiotics improves the growth, survival, and microbial community of juvenile white leg shrimp, (Litopenaeus vannamei). Journal of Applied Aquaculture, 1-17.

[76] Garriques D and Arevalo G. (1995). An evaluation of the production and use of a live bacterial isolate to manipulate the microbial flora in the commercial production of (Penaeus vannamei) post larvae in Ecuador. In: Swimming Through Troubled Waters. Proceedings of the Special Session on Shrimp Farming (ed. by C.L. Browd and J.S. Hopkins), World Aquaculture Society, Baton Rouge, USA, 53-59.

[77] Guzman-Villanueva LT, Escobedo-Fregoso C, Barajas-Sandoval DR, Gomez-Gil B, Pena-Rodríguez A, MartínezDiaz SF and Quiroz-Guzman E. (2019). Assessment of microbial dynamics and antioxidant enzyme gene expression following probiotic administration in farmed Pacific white shrimp (Litopenaeus vannamei). Aquaculture, 519, 734907.

[78] Fernandez R, Sridhar M and Sridhar N. (2011). Effect of Lactic acid bacteria administered orally on growth performance of (Penaeus indicus) (H. Milne Edwards) juveniles. Research Journal of Microbiology, 6, 466-479. 
[79] Braiek OB, Ghomrassi H, Cremonesi P, Morandi S, Fleury Y, Chevalier PL, Hani K, Hadj OB and Ghrairi T. (2017). Isolation and characterisation of an enterocin P-producing Enterococcus lactis strain from a fresh shrimp (Penaeus vannamei). Antonie van Leeuwenhoek, 110, 771-786.

[80] Nami Y, Abdullah N, Haghshenas B, Radiah D, Rosli R and Khosroushahi AY. (2014). Probiotic assessment of Enterococcus durans $6 \mathrm{HL}$ and Lactococcus lactis $2 \mathrm{HL}$ isolated from vaginal microflora. Journal of Medical Microbiology, 63, 1044-1051.

\section{How to cite this article}

Jain IB, Bhavan PS, Dharani C, Manjula T, Kalpana R, Muralisankar T, Karthik M and Puvitha P. (2020). Growth and survival promotion of a probiotic bacterium Enterococcus durans enriched Artemia nauplii on the prawn Macrobrachium rosenbergii. GSC Biological and Pharmaceutical Sciences, 12(1), 87-101. 